\title{
AGROSSTA
}

Journal Agroista. Vol. 5 ,No.2 November 2021

Journal home page: https://jurnal.instiperjogia.ac.id/index.php/AGl

ISSN : $2597-3835$ e-ISSN : $2684-7019$

\section{HUBUNGAN TATA KELOLA AIR PADA LAHAN GAMBUT DENGAN PRODUKTIVITAS KELAPA SAWIT DI PT. UNI PRIMACOM, DESA BARUNANG MIRI, KECAMATAN PARENGGEAN, KABUPATEN KOTAWARINGIN TIMUR, KALIMANTAN TENGAH}

\author{
Enny Rahayu*, Muhammad Anditia Basith, Dian Pratama Putra \\ ${ }^{1}$ Department of Agrotechnology, Faculty of Agriculture, Stiper Agricultural Institute, \\ Yogyakarta, Indonesia \\ Email Korespondensi: ennyrahayu@instiperjogja.ac.id
}

\begin{abstract}
ABSTRAK
Penelitian ini bertujuan mengkaji sistem tata kelola air pada lahan gambut dan pengaruhnya terhadap produksi Kelapa Sawit. Kajian ini dilaksanakan di PT. Uni Primacom Desa Barunang Miri, Kecamatan Parenggean, Kabupaten Kotawaringin Timur, Provinsi Kalimantan Tengah pada bulan Juli sampai dengan Oktober 2020. Metoda penelitian yang digunakan adalah metode survey yang terdiri dari dua tahap yaitu tahap pertama Survey Pendahuluan dan tahap kedua adalah Survey Utama. Survey pendahuluan dilakukan untuk menentukan tempat penelitian dan sampel tanaman. Survey utama dilakukan untuk pengambilan data baik data primer maupun data sekunder. Data yang diperoleh dianalisis dengan menggunakan Regresi Korelasi dalam 2 tipe yaitu Regresi Linier sederhana dan Regresi polinomial sederhana. Data yang dibutuhkan adalah data primer yang meliputi : a) pengamatan tingkat kematangan gambut dan b) kedalaman gambut, sedangkan data sekunder yang dibutuhkan adalah : a) water table (th 2015 - 2018), b) curah hujan bulanan (th 2011 - 2020), c) hari hujan (th 2011 - 2020), d) produksi kelapa sawit (ton/ha) (th 2015 - 2018). Hasil penelitan menunjukkan bahwa tidak ada korelasi antara curah hujan dengan tinggi muka air tanah (Water Table) dengan persamaan Regresi yang dipilih adalah Regresi linier sederhana dengan persamaan $Y=48,629-0,0612 X$ dengan koefisien korelasi $(R \wedge 2)$ adalah 0,331 artinya persamaan Regresi diatas menunjukkan semakin tinggi $X$ (curah hujan) maka semakin rendah $\mathrm{Y}$ (Water Table), dan tidak ada hubungan yang erat antara curah hujan dengan tinggi muka air (Water table). Untuk hubungan antara curah hujan dengan produksi pun juga diperoleh hubungan yang tidak erat dengan nilai koefisien korelasi $(R \wedge 2)$ 0,4017 dengan persamaan Regresi Linier sederhana yaitu $Y=17,319+0,0465 X$, artinya semakin tinggi $X$ (curah hujan) maka semakin tinggi $Y$ (produksi kelapa sawit. Sedangkan hubungan antara tinggi muka air tanah (Water Table) dengan produksi Kelapa sawit diperoleh persamaan regresi Linier sederhana dengan persamaan $Y=48,678-0,601 \mathrm{X}$ dan nilai koefisien korelasi nya $(R \wedge 2)=0,759$. Hal ini menunjukkan bahwa ada hubungan yang erat antara water table dengan produksi kelapa sawit, semakin tinggi (semakin dalam) X (water table) maka produksi
\end{abstract}


kelapa sawit semakin $(Y)$ semakin rendah. Dari hasil analisis tersebut maka dapat diambil kesimpulan bahwa pengelolaan air di areal gambut pada PT UNI PRIMACOM, Desa Barunang Miri, Kecamatan Parenggean, Kabupaten Kotawaringin Timur, Kalimantan Tengah sudah bagus, yang ditunjukkan oleh tidak adanya hubungan yang erat antara curah hujan dengan tinggi muka air, dan curah hujan dengan produksi, tetapi produksi kelapa sawit justru dipengaruhi oleh tinggi muka air tanah (Water Table) yang ada campur tangan management.

Kata kunci : Lahan Gambut, Tata Kelola Air, Produktivitas Kelapa sawit. 


\section{PENDAHULUAN}

Budidaya kelapa sawit pada lahan gambut selalu melibatkan pengelolaan tata air, pemadatan tanah, dan pemupukan, dan jika ketiga faktor tersebut tidak dikelola dengan baik, kelestarian lahan gambut akan terancam. Pengelolaan tata air yang buruk akan berpengaruh secara signifikan terhadap penurunan produksi. Level air yang terlalu rendah akan meningkatkan laju subsiden dan resiko kecelakaan kebakaran gambut. Drainase yang buruk akan menyebabkan kondisi kering tak balik (irreversible). Oleh karena itu pengelolaan tata air adalah syarat awal keberhasilan pengelolaan lahan gambut (Melling dan Hatano, 2010). Kriteria lahan gambut untuk kebun kelapa sawit harus memenuhi Peraturan Menteri Pertanian (PERMENTAN) Nomor 14/Permentan/ PL.110/2/2009 Tahun 2009. Menurut Hatano et al. (2010) level air merupakan faktor penting dalam menentukan regulasi emisi gas rumah kaca pada tanah gambut. Level air yang semakin rendah akan meningkatkan emisi CO2 dan N2O, sedangkan kondisi banjir akan menghasilkan emisi $\mathrm{CH} 4$. Oleh karena itu level air diusahakan pada kisaran 50-75 cm di bawah permukaan tanah. (Saragih, 2013).

Berdasarkan proses pembentukan dan sumber unsur hara yang diperoleh, yakni gambut ombrogen dan gambut topogen. Dengan diberlakukannya Permentan no. 14/2009 tentang Pedoman Pemanfaatan Lahan Gambut untuk Budidaya Kelapa Sawit, pemanfaatan lahan gambut menjadi urgen sehubungan dengan fungsi lahan gambut untuk aspek konservasi dan mencegah degradasi lahan gambut. Gambut ombrogen berkembang dari depresi dangkal yang kemudian naik membentuk kubah dan berada di atas muka air tanah. Selama proses pembentukan, lahan gambut umumnya memperoleh unsur hara dari air hujan sehingga miskin kesuburan dan $\mathrm{pH}$ sangat rendah sampai dengan rendah, Sedangkan gambut topogen terbentuk dari pengaruh luapan pasang surut air dan biasanya memperoleh unsur hara akibat masuknya nutrisi dan dari sedimentasi mineral selama masa luapan air tadi sehingga lebih subur dan $\mathrm{pH}$ rendah. Akibat perbedaan pedogenesis tanah mineral dan gambut, maka karakter tanah gambut berbeda dengan tanah mineral, antara lain bobot isi sangat rendah $(0,1-0,3 \mathrm{~g} / \mathrm{cm} 3$, tanah mineral = 1,60 - 1,70 g/cm3 ), Kandungan unsur hara sangat rendah, kecuali unsur N, Kapasitas retensi unsur hara kecil, khususnya terhadap K, Fiksasi cepat terhadap $\mathrm{Cu}$ dan $\mathrm{Zn}$ terlarut oleh senyawa asam humat, fulvat dan senyawa polyphenol, pH sangat rendah - rendah $(2-4,5)$, Kandungan bahan organik sangat tinggi (sampai 98\%) yang beresiko terhadap kebakaran bila kering, dan kapasitas memegang air sangat tinggi. Oleh karena itu kajian kesesuaian lahan untuk pengembangan kelapa sawit khususnya di lahan gambut perlu dilakukan.

Pengelolaan tata air di lahan gambut merupakan faktor kunci terwujudnya sistem pengelolaan lahan gambut berkelanjutan. Perubahan penggunaan lahan khususnya dari hutan gambut menjadi lahan pertanian perlu disertai dengan tindakan tata kelola air yang baik, karena dalam kondisi yang sebenarnya gambut dalam keadaan tergenang, sementara 
kebanyakan tanaman budidaya tidak tahan terhadap genangan. Oleh karena itu tujuan utama dilakukannya tata kelola air pada lahan gambut adalah untuk menurunkan muka air tanah sehingga terciptanya kondisi aerob, minimal sampai pada kedalaman perakaran tanaman yang di budidayakan sehingga kebutuhan akan oksigen pada tanaman dapat terpenuhi. Tujuan lain dilakukannya tata kelola air pada lahan gambut adalah untuk membuang sebagaian asam asam organik yang dapat meracuni tanaman. Pada tanaman kelapa sawit yang ditanam dilapangan yang tergenang hasilnya kerdil dan hasilnya rendah, dikarenakan metabolisme untuk melakukan siklus hidupnya (anabolisme dan katabolisme) anabolisme yaitu fotosintesis, katabolisme yaitu respirasi.

Hukum kekekalan energi berbunyi. Energi dapat berubah dari satu bentuk ke bentuk yang lain tetapi tidak bisa diciptakan atau dimusnahkan. Permasalahan pada tanah tergenang adalah keadaan tanah yang aerob yaitu kekurangan udara sehingga yang tidak berjalan adalah proses respirasi sehingga tidak terbentuk energi padahal energi dibutuhkan oleh tanaman untuk pertumbuhan dan perkembangan produksi. Upaya agar tanaman tumbuh dengan baik dan menghasilkan produksi yang tinggi adalah dengan membuah air yang menggenang harus dibuang sampai kapasitas lapang hingga kedalaman tertentu. Kedalaman muka air dalam tanah disebut water table, water table ini dibuat guna untuk menyediakan proses perakaran yang aerob namun water table pada tanah gambut dimaksudkan juga untuk menjaga kelembaban tanah yang berada diatasnya agar tidak mengalami irreversible drying, irreversible drying yaitu kering tak balik yang menunjukkan kadar lengas tertentu dimana gambut mengalami kekeringan yang ekstrim sehingga tidak mampu menyerap air kembali karena kemampuan menyerap air hilang maka gambut tersebut rentan terhadap api sehingga mudah terbakar, untuk itu water table pada gambut kedalamannya disesuaikan dengan tingkat kematangannya. Tingkat kapileritas atau pembasahan gambut di pengaruhi oleh faktor kematangan gambut yaitu :

1. Gambut matang (Saprik) $=70 \mathrm{~cm}$

2. Gambut $1 / 2$ matang $($ Hemik $)=50 \mathrm{~cm}$

3. Gambut mentah ( Fibrik) $=40 \mathrm{~cm}$

Sehingga untuk menjaga agar gambut tidak mengalami irreversible drying maka water table disesuaikan tingkat kapileritas atau tingkat pembasahan gambut tersebut. Cara menentukan tingkat gambut dengan metode perasan adalah sebagai berikut, ambil gambut yang kalau diperas keluar $70 \%$ maka gambut itu matang, 50\% setengah matang, 30\% mentah. Padahal kelapa sawit membutuhkan zona perakaran kelas $\mathrm{S} 1=80-85 \%$ sehingga ditambahkan tapak kuda

Menurut Saragih (2019) bahwa nutrisi yang terdapat didalam tanah dipengaruhi juga oleh pH tanah dan Kapasitas Tukar Kation (KTK) sehingga perlunya evaluasi terhadap 2 parameter tersebut adalah mutlak. Hal ini juga diperkuat dengan penelitan yang dilakukan 
Putra (2020) bahwa mayoritas banyaknya hara yang hilang dipengaruhi oleh air ataupun aliran air, baik dari air hujan ataupun aliran pada Daerah Aliran Sungai (DAS) sehingga akan mempengaruhi kualitas air dan mengganggu ekosistem sekitar DAS.

\section{METODOLOGI}

1. Waktu dan Tempat Penelitian

Penelitian akan dilakukan di PT. Uni Primacom desa Barunang Miri, Kec Parenggean, Kab Kotawaringin Timur, Provinsi Kalimantan Tengah pada bulan Juni sampai Juli 2020.

2. Alat dan Bahan

a. Alat yang digunakan adalah alat tulis, meteran.

b. Bahan yang digunakan adalah data produksi 10 tahun terakhir, data iklim 10 tahun terakhir, Peta sebaran tanaman yang tergenang, luasan lahan yang tergenang air

\section{Rancangan Penelitian}

Penelitian ini menggunakan métode survey yang terdiri dari dua tahap yaitu (1) Survey Pendahuluan dan (2) Survey Utama, Survey pendahuluan dilakukan untuk menentukan tempat penelitian dan pengambilan data data sekunder baik yang ada diperusahaan maupun instansi terkait. Survey Utama dilakukan untuk menentukan titik sampel pengamatan dan pengambilan data primer. Data primer mengukur kedalaman air dari permukaan tanah, kedalaman lahan gambut, tingkat kematangan lahan gambut, sifat fisik tanah. Data sekunder yang dibutuhkan yaitu Data iklim 10 tahun terakhir, Data Produksi 10 tahun terakhir, Data luasan lahan yang tergenang, Peta lahan yang tergenang dan layout jaringan drainase. Data yag didapat kemudian dianalisis dengan menggunakan regresi.

\section{HASIL DAN PEMBAHASAN}

\section{A. Deskripsi Perusahaan}

PT. Uni Primacom merupakan perusahaan swasta yang bergerak dalam bidang perkebunan kelapa sawit dibawah naungan Musirawas Group. Musirawas Group terdapat 4 (empat) Perusahaan yaitu PT. Musirawas Citraharpindo, PT. Uni Primacom, PT. Sumur Pandanwangi dan PT. Kartika. PT. Uni Primacom terletak di desa Barunang Miri, Kecamatan Parenggean, Kabupaten Kotawaringin Timur, Provinsi Kalimantan Tengah. Wilayah PT. Uni Primacom dibagi menjadi 2 area yakni Area Sei Pudu dan Sei Kaliman. Dan terdiri dari 11 (sebelas) divisi yaitu divisi H,I,J,K,L,M,N,O,SW,V,Z. Memiliki 2 (dua) PKS yaitu PKS 1 dan PKS 2 serta terdapat 4 (empat) kemitraan yaitu Koperasi Omang Sabar, Kelompok Tani Ubi Hapakat, Kelompok tani Kapakat Itah Pahari dan Koperasi Sangsang Raya Makmur , Topografi kebun mulai dari berbukit, rendahan dan lahan gambut. Diperusahaan ini memiliki tahun tanam yang berbeda yakni tahun tanam 1997 sebagai tanaman tertua dan 2013 sebagai 
tanaman termuda yang sudah menghasilkan. Blok yang akan diamati berada di divisi O pada blok C46,C47 yang memiliki tahun tanam dari tahun 2008 sampa 2011. Waktu penelitian dilaksanakan pada bulan Juni s/d Oktober 2020.

C. Curah Hujan di Kebun PT. Uni Primacom

Pada Penelitian kali ini menggunakan data curah hujan tahunan selama 10 tahun. Dari hasil penelitian dilapangan diperoleh rerata curah hujan disetiap tahun dari tahun 2011-2020.

Tabel 1. Total Curah Hujan(mm) dan Hari Hujan (hari) tahun 2011-2020.

\section{B. Peta Plot Penelitian di PT. Uni Primacom}
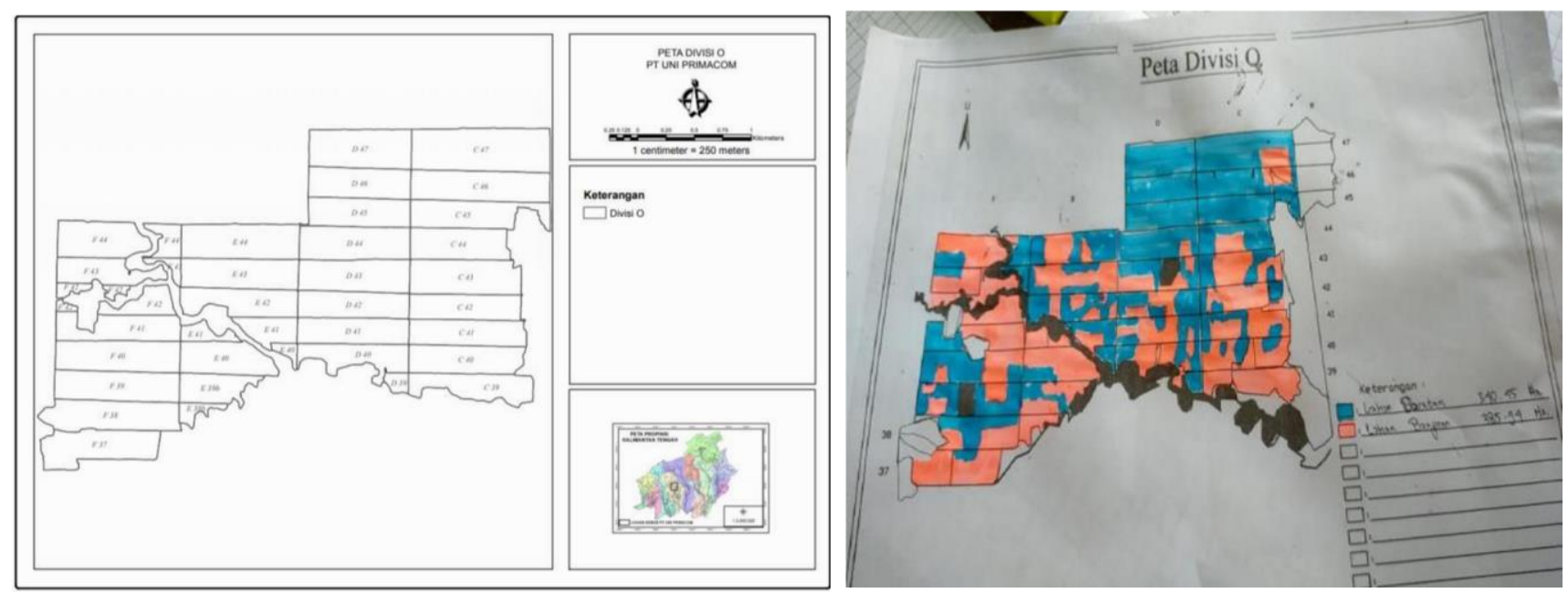

Gambar 1. Peta blok Penelitian (Kiri) dan Peta sebaran daerah banjir (biru) (Kanan)

\begin{tabular}{cccccc} 
Tahun & $\begin{array}{c}\text { Hari } \\
\text { Hujan }\end{array}$ & $\begin{array}{c}\text { Curah } \\
\text { Hujan }\end{array}$ & $\begin{array}{c}\text { Bulan } \\
\text { Basah }\end{array}$ & $\begin{array}{c}\text { Bulan } \\
\text { Lembab }\end{array}$ & $\begin{array}{c}\text { Bulan } \\
\text { Kering }\end{array}$ \\
\hline 2011 & 85 & 1.817 & 10 & 1 & 1 \\
2012 & 85 & 2.287 & 10 & 1 & 1 \\
2013 & 90 & 2.477 & 12 & 0 & 0 \\
2014 & 66 & 1.797 & 8 & 0 & 4 \\
2015 & 75 & 1.853 & 8 & 1 & 3 \\
2016 & 92 & 2.684 & 12 & 0 & 0 \\
2017 & 95 & 2.992 & 12 & 0 & 0 \\
2018 & 112 & 2.688 & 11 & 1 & 0 \\
2019 & 115 & 3.456 & 10 & 1 & 1 \\
2020 & 80 & 2.306 & 8 & 0 & 0 \\
Rerata & 81,5 & 2.205 & 9,3 & 0,5 & 1 \\
\hline
\end{tabular}


D. Hubungan antara Curah Hujan dengan Ketinggian Muka Air Tanah Tabel

2. Curah Hujan dan Tinggi Muka Air Tanah

\begin{tabular}{ccc}
\hline Tahun & CH & TMAT \\
\hline 2015 & 154 & 42,4 \\
2016 & 223 & 39,3 \\
2017 & 249 & 35 \\
2018 & 224 & 32,9 \\
2019 & 288 & 30,6 \\
2020 & 192 & 30,2
\end{tabular}

Berikut ini adalah data antara tinggi muka air tanah dengan produktivitas tahun 2015 - 2020 PT. Uni Primacom Blok C46.

Dinamika water table selama 4 tahun di PT. Uni Primacom cenderung stabil dan tidak mengalami kenaikan ataupun penurunan yang signifikan, ini dapat dilihat dari tahun 2015 dengan curah hujan rata rata pertahun $154 \mathrm{~mm}$ ketingggian muka air tanah $42,4 \mathrm{~cm}$, pada tahun 2016 curah hujan $223 \mathrm{~mm}$ dengan ketinggian muka air $39,3 \mathrm{~cm}$, pada tahun 2017 curah hujan kembali naik yaitu sebesar $249 \mathrm{~mm}$ dan tinggi muka airnya naik menjadi 35cm, pada tahun 2018 curah hujan 224 mm ketnggian muka air tanah $32,9 \mathrm{~cm}$, artinya pengelolaan air pada saat musim hujan dengan intensitas tinggi maupun musim kemarau dapat dijaga ketersediaan air didalam tanah agar tidak kering dan tidak tenggelam ini disebebkan terdapatnya saluran baik irigasi sebagai tampungan air selama musim kemarau dan drainase sebagai pembuangan air agar tidak mengenang.

\section{Pengaruh Curah Hujan Terhadap Tinggi Muka Air} Tanah

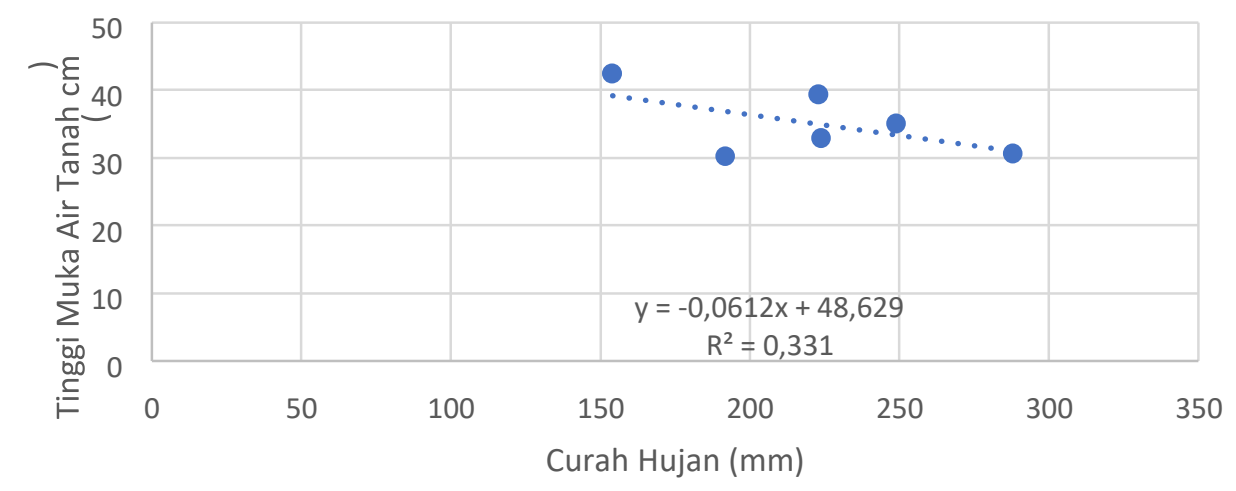

Gambar 2. Grafik Hubungan Antara Curah Hujan dan Tinggi Muka Air Tanah 
Dilihat dari nilai koefisien regresi $(-0,0612 \mathrm{X})$ pada Gambar 2. Menunjukkan bahwa Curah Hujan memberikan pengaruh terhadap tinggi muka air, sedangkan dilihat dari nilai koefisien korelasi dari gambar tersebut menunjukkan nilai yang mendekati 0 yaitu 0,331 yang artinya hubungan antara curah hujan dengan tinggi muka air tanah memiliki hubungan yang lemah atau tidak erat dikarenakan diterapkannya pengelolaan air pada lokasi sampel dan sudah berjalan dengan baik dalam mengatur ketinggian muka air agar tidak melebihi ambang batas.

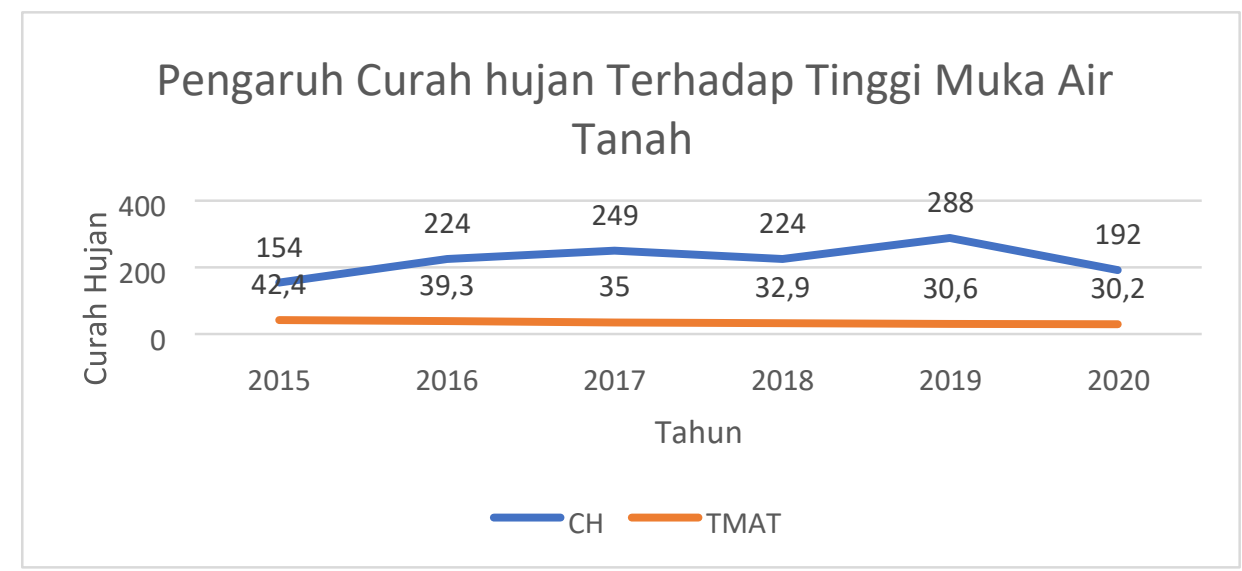

Gambar 3. Grafik Pengaruh Curah Hujan Terhadap Tinggi Muka Air Tanah

Dari grafik pengaruh curah hujan terhadap tinggi muka air tanah di PT. Uni Primacom tahun 2015 - 2020 dapat dilihat curah hujan dari tahun ke tahun semakin tinggi kecuali pada tahun 2018, namun curah hujan tidak terlalu berpengaruh atau memiliki pengaruh yang tidak kuat, hal ini dapat disebabkan oleh terkelolanya sistem tata kelola air yang dilakukan sudah baik.

E. Hubungan Antara Curah Hujan Dengan Tinggi Muka Air Tanah

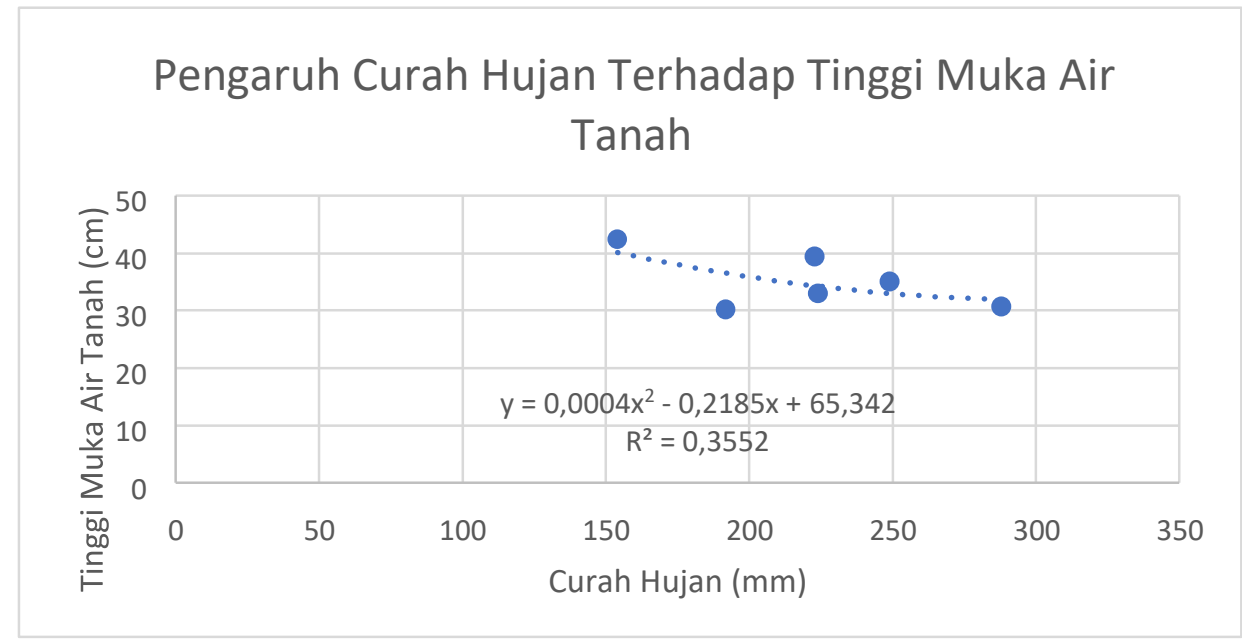

Gambar 4. Grafik Hubungan Antara Curah Hujan Dengan Tinggi Muka Air Tanah 
Dari hasil analisis regresi kuadratik antara curah hujan terhadap tinggi muka air tanah menunjukkan semakin tinggi nilai $X$ (Curah Hujan) maka nilai $Y$ (Tinggi Muka Air Tanah) semakin rendah atau turun.

Hasil analisis regresi pada gambar 4 dengan persamaan $y=0,0612 x+48,629$ dan korelasinya $\left(R^{2}\right)=0,331$ menunjukkan curah hujan berpengaruh terhadap tinggi muka air tanah namun tidak kuat dengan kata lain curah hujan yang tinggi maupun rendah masih dapat dikontrol ketersediaan air maupun kelebihan airnya karena apabila curah hujan tinggi terdapat drainase dan apabila curah hujan rendah terdapat irigasi, dengan begitu kebutuhan tanaman kelapa sawit akan air dapat dipenuhi dengan baik.

Hubungan antara tinggi muka air tanah dengan produksi dengan hasil analisis regresi yaitu y $=-0,6005 x+48,678$ dan nilai koefisien korelasi $\left(R^{2}\right)=0,7585$ menjelaskan bahwa tinggi muka air tanah memiliki pengaruh yang kuat terhadap produktivitas kelapa sawit apabila dapat menjaga tinggi muka air didalam tanah, dilihat pada tahun 2015 curah hujan rendah disebabkan terjadinya peristiwa el nino pada tahun tersebut namun dari gambar 5 bahwasannya ketinggian muka air tanah cenderung stabil dan tidak melebihi $60 \mathrm{~cm}$, seperti yang tertuang dalam Peraturan Menteri Pertanian No.14/2009 tinggi muka air tanah (TMA) sebaiknya pada kisaran 0,6 meter - 0,8 meter terbukti lebih baik dalam hal produktivitas kelapa sawit, akar yang paling aktif menyerap air dan unsur hara adalah akar tersier dan kuartener berada di kedalaman 0-60 cm dengan jarak 2-3 meter dari pangkal pohon (Lubis dan Agus, 2011). Dari analisis pada gambar 10 dengan persamaan regresi $y=0,0465 x+17,319$ dan korelasi $\left(R^{2}\right)=0,4017$ menunjukkan bahwa curah hujan memiliki pengaruh yang tidak kuat terhadap produksi hal ini dikarenakan telah terkelolanya tata kelola air yang baik di tempat pengambilan sampel.

Menurut I. Las, K. Nugroho dan A. Hidayat (2009), kunci utama keberhasilan pengembangan lahan pertanian di lahan gambut adalah pengaturan tata lahan dan air (soil dan water management) yang sesuai dengan karakteristik air di daerah tersebut. Tata kelola air pada lahan gambut untuk tanaman dikatakan bagus apabila dapat memenuhi kebutuhan air bagi tanaman kelapa sawit agar tidak kelebihan ataupun kekurangan air, lahan gambut dalam kondisi alaminya gambut dalam keadaan yang tergenang sedangkan sebagaian besar tanaman tidak kuat terhadap genangan, oleh karena itu tujuan dari jaringan drainase adalah membuang kelebihan air dan menurunkan muka air tanah sehingga tercipta kondisi yang aerob sampai ke kedalaman perakaran yang dibudidayakan, membuang kelebihan air dapat dengan cara membuka pintu air agar air dapat diloloskan sehingga tidak sampai menggenang. Jaringan irigasi digunakan untuk mengalirkan air pada saat musim kemarau agar kebutuhan tanaman akan air dapat terjaga. 
F. Hubungan Antara Tinggi Muka Air Tanah dengan Produktivitas Tabel

3. Tinggi Muka Air Tanah Dan Produksi

\begin{tabular}{ccc}
\hline Tahun & TMAT & Produksi \\
\hline 2015 & 42,4 & 23,61 \\
2016 & 39,3 & 23,9 \\
2017 & 35 & 27,46 \\
2018 & 32,9 & 31,33 \\
2019 & 30,6 & 31,23 \\
2020 & 30,2 & 28,19 \\
\hline
\end{tabular}

Berikut ini adalah data antara tinggi muka air tanah dengan produktivitas tahun 2015 _ 2020 PT. Uni Primacom Blok C46.

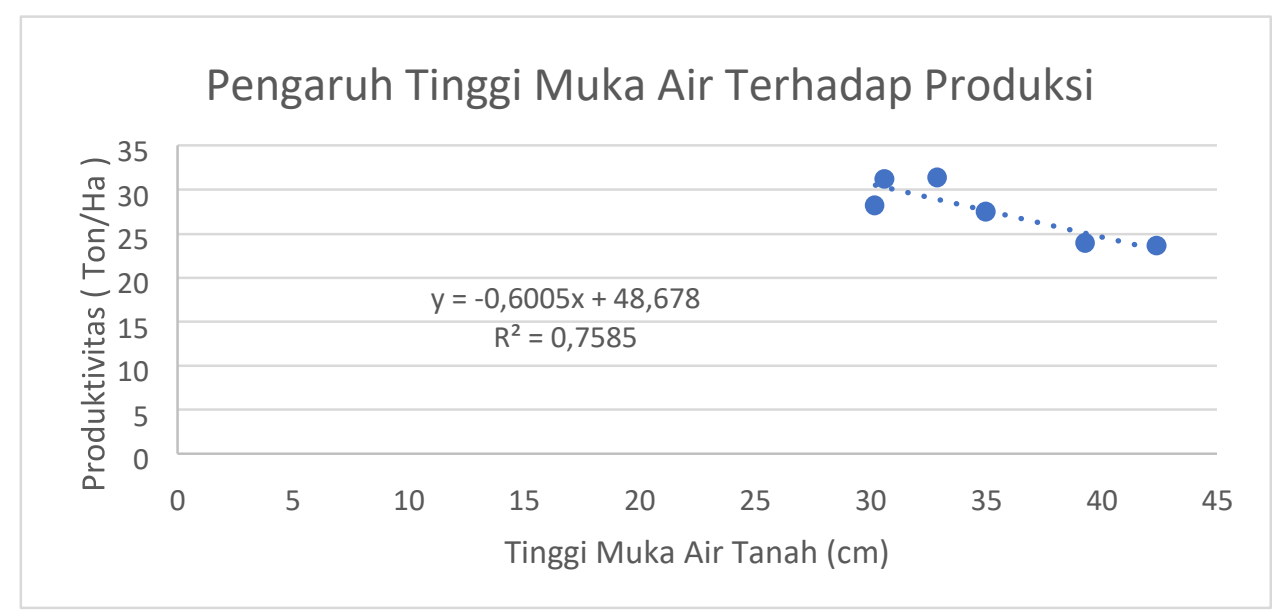

Gambar 5. Grafik Pengaruh Tinggi Muka Air Tanah dan Produksi.

Dilihat dari nilai koefisien regresi $(-0,6005 \mathrm{X})$ pada Gambar 5. Menunjukkan bahwa Tinggi Muka Air Tanah memberikan pengaruh terhadap Produktivitas Kelapa Sawit, sedangkan dilihat dari nilai koefisien korelasi dari gambar tersebut menunjukkan nilai yang mendekati 1 yaitu 0,7585 yang artinya hubungan antara Tinggi Muka Air Tanah dengan Produktivitas Kelapa Sawit memiliki hubungan yang kuat 


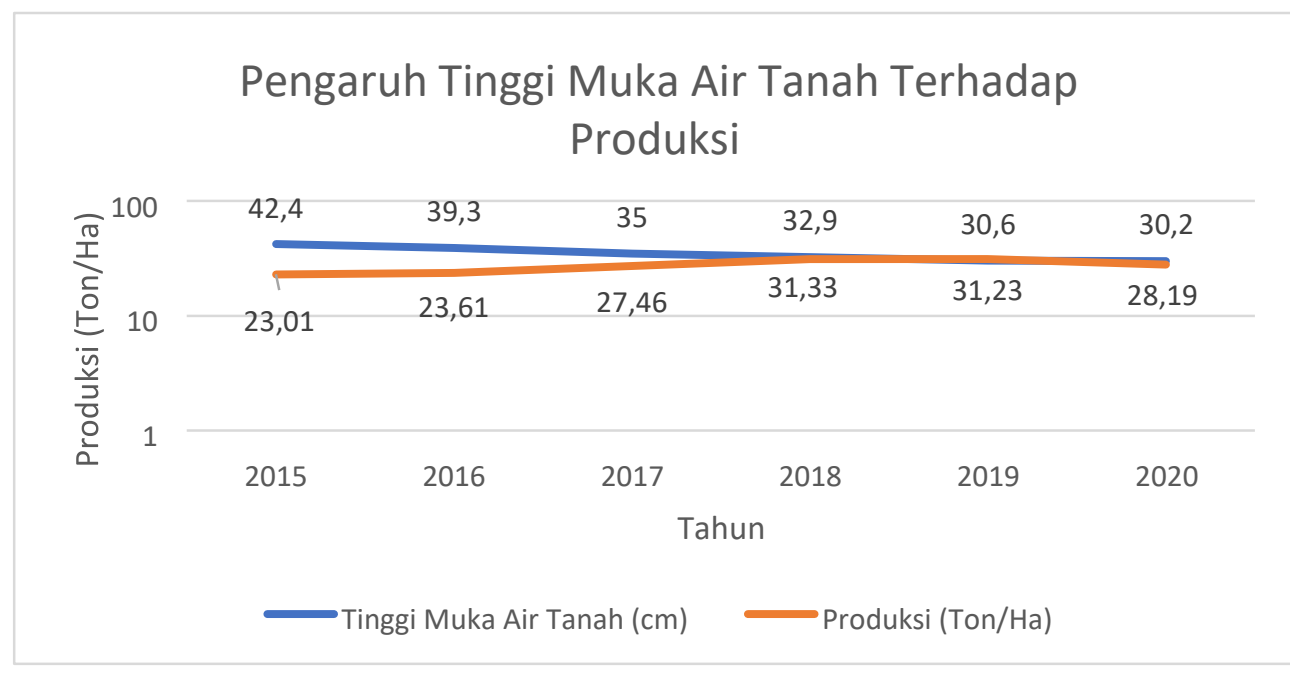

Gambar 6. Grafik Hubungan Tinggi Muka Air Tanah Terhadap Produksi

Dari grafik hubungan tinggi muka air tanah terhadap produksi pertahun tahun 2015 - 2020 di PT. Uni Primacom Barunang Miri, Kalimantan Tengah dapat dilihat pada tahun 2019 produksi mengalami penurunan dikarenakan curah hujan yang tinggi pada tahun 2019, tetapi pada saat curah hujan tinggi, tinggi muka air tanah tidak turun signifikan dikarenakan telah terkelolanya sistem tata kelola air yang baik.

G. Hubungan Antara Tinggi Muka Air Tanah dengan Produktivitas

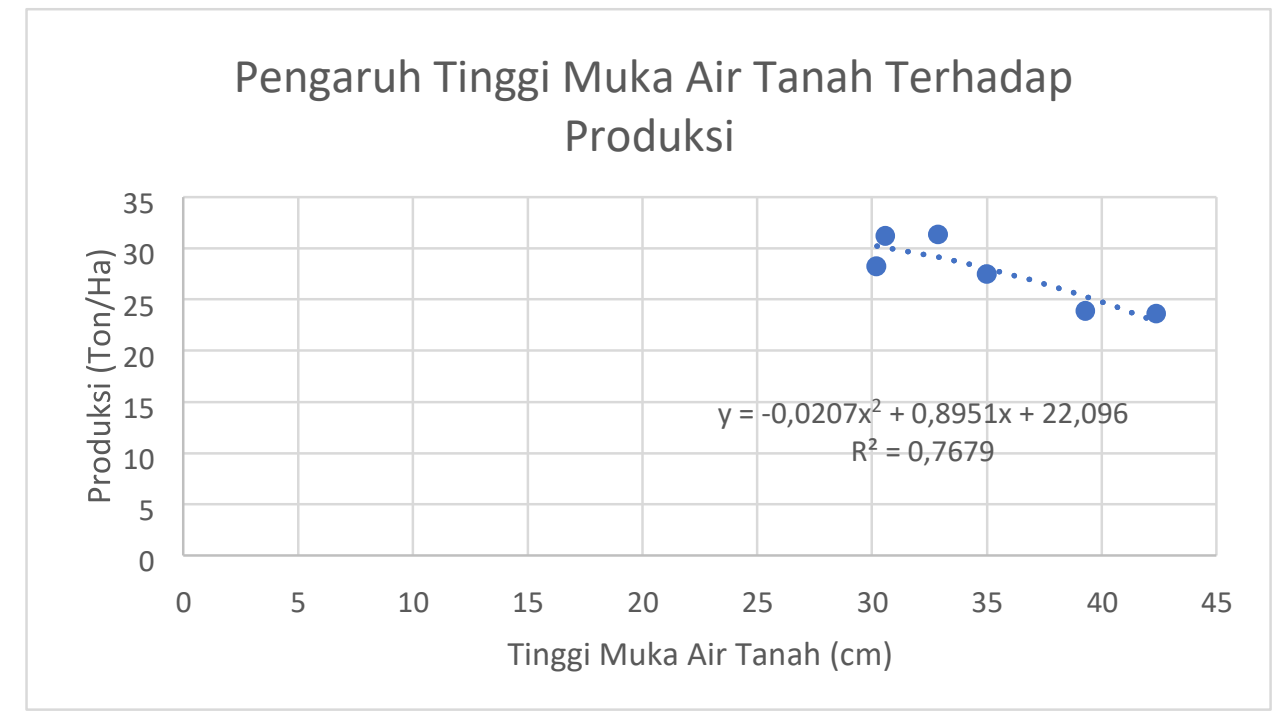

Gambar 7. Grafik pengaruh Tinggi Muka Air Tanah Terhadap Produksi

Dari hasil analisis regresi kuadratik antara tinggi muka air tanah terhadap produksi menunjukkan semakin tinggi nilai $X$ maka Ynya semakin tinggi sampai nilai $X$ tertentu

I. Hubungan Antara Curah Hujan dengan Produktivitas Tabel

\section{Curah Hujan Dan Produksi}

\begin{tabular}{cc}
\hline Curah Hujan (mm) & Produksi (ton/ha) \\
\hline 154 & 23,61
\end{tabular}


Berikut ini adalah data antara Curah Hujan dengan Produktivitas tahun 2015 2020 PT. Uni Primacom blok C46

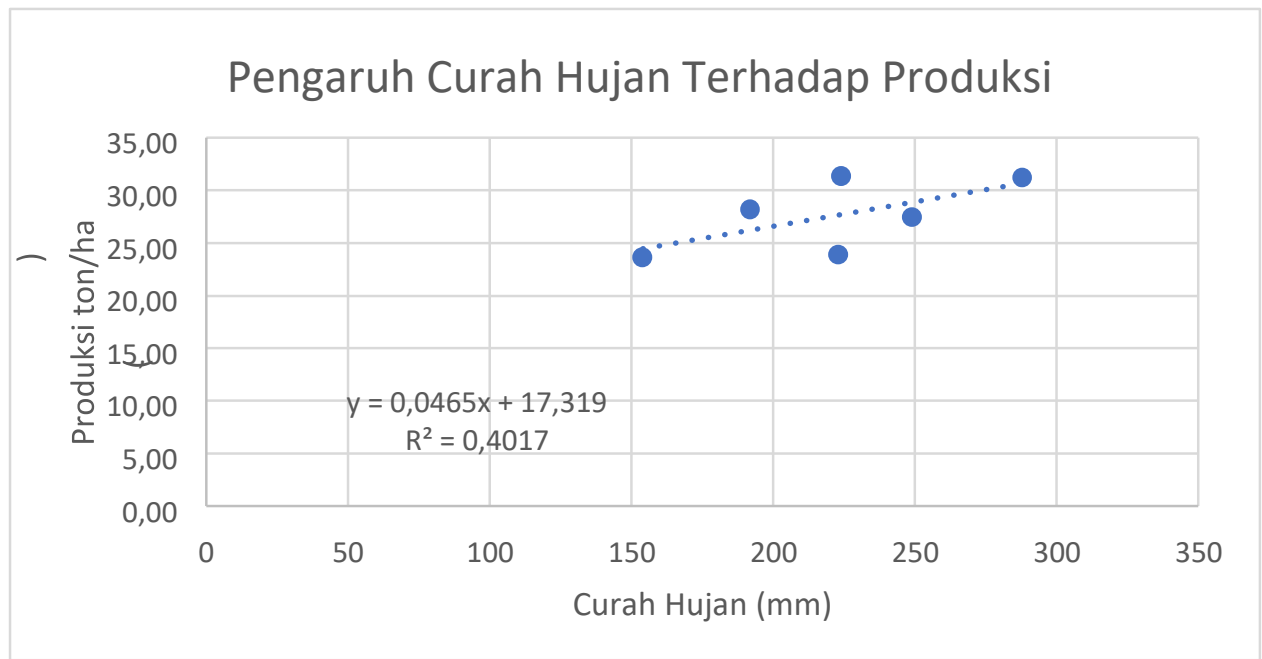

Gambar 8. Grafik Pengaruh Curah Hujan Terhadap Produksi

Dilihat dari nilai koefisien regresi $(0,0465 \mathrm{X})$ pada Gambar 8. Menunjukkan bahwa memberikan pengaruh terhadap produktivitas kelapa sawit, sedangkan dilihat dari nilai koefisien korelasi dari gambar tersebut menunjukkan nilai yang mendekati 0 yaitu 0,4017 yang artinya hubungan antara curah hujan dengan produktivitas kelapa sawit memiliki hubungan yang lemah.

J. Produktivitas Kelapa Sawit Pada tahun 2011-2020

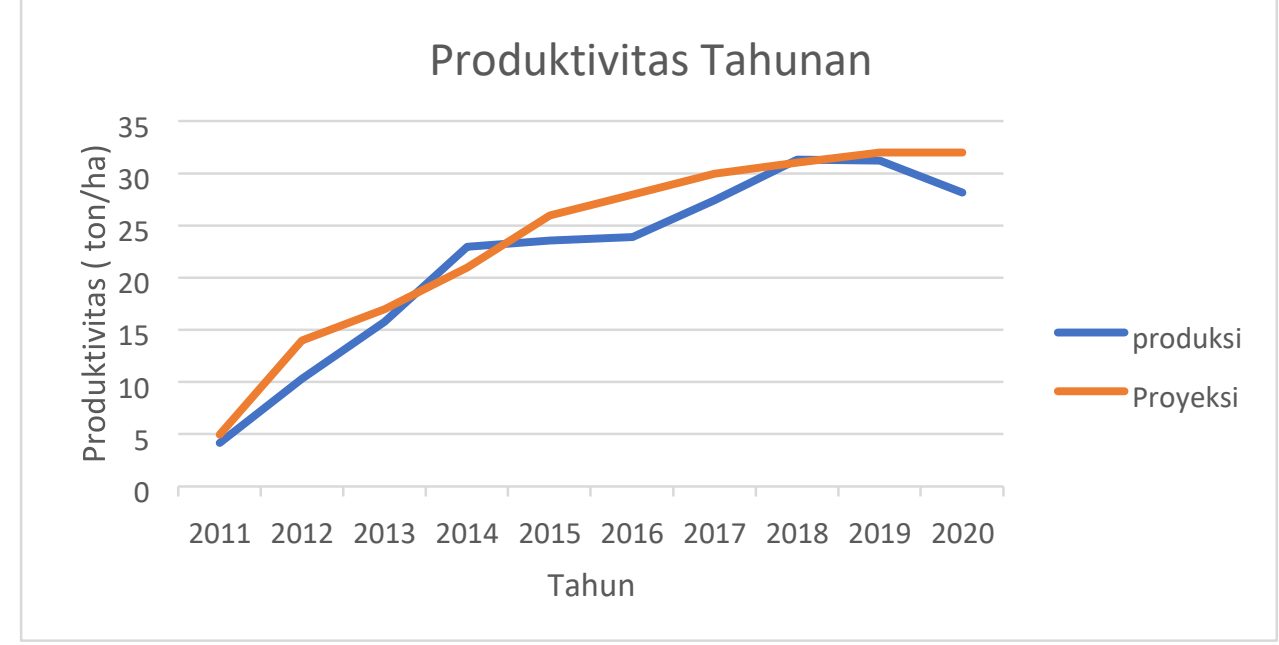

Gambar 9. Produksi di blok C46 Pada Tahun 2011-2020 
Pada Gambar 9. Menunjukkan bahwa grafik produktivitas kelapa sawit terus meningkat dari tahun 2011-2014, pada tahun 2014-2016 produksi relativ stabil, dan pada tahun 2017-2018 meningkat kembali, pada tahun 2019 blok C46 terjadi penurunan produksi diduga diakibatkan curah hujan yang tinggi sehingga produktivitas menurun.

K. Berat Janjang Rata-Rata

Tabel 5. Berat Janjang Rata-Rata tahun 2011-2020

\begin{tabular}{ccccr}
\hline TM & Tahun & BJR & Standar & Proyeksi \\
\hline 3 & 2011 & 2,57 & 3 & $85,60 \%$ \\
4 & 2012 & 3,79 & 4 & $94 \%$ \\
5 & 2013 & 4,62 & 6 & $77 \%$ \\
6 & 2014 & 5,72 & 8 & $71,50 \%$ \\
7 & 2015 & 6,77 & 8 & $84,60 \%$ \\
8 & 2016 & 8,28 & 10 & $82,80 \%$ \\
9 & 2017 & 11,08 & 11 & $100,70 \%$ \\
10 & 2018 & 11,67 & 13 & $89,70 \%$ \\
11 & 2019 & 11,81 & 17 & $69 \%$ \\
12 & 2020 & 13,78 & 17 & $81 \%$
\end{tabular}

Berikut ini data berat janjang rata rata tahun 2011 - 2020 PT. Uni Primacom Blok C46

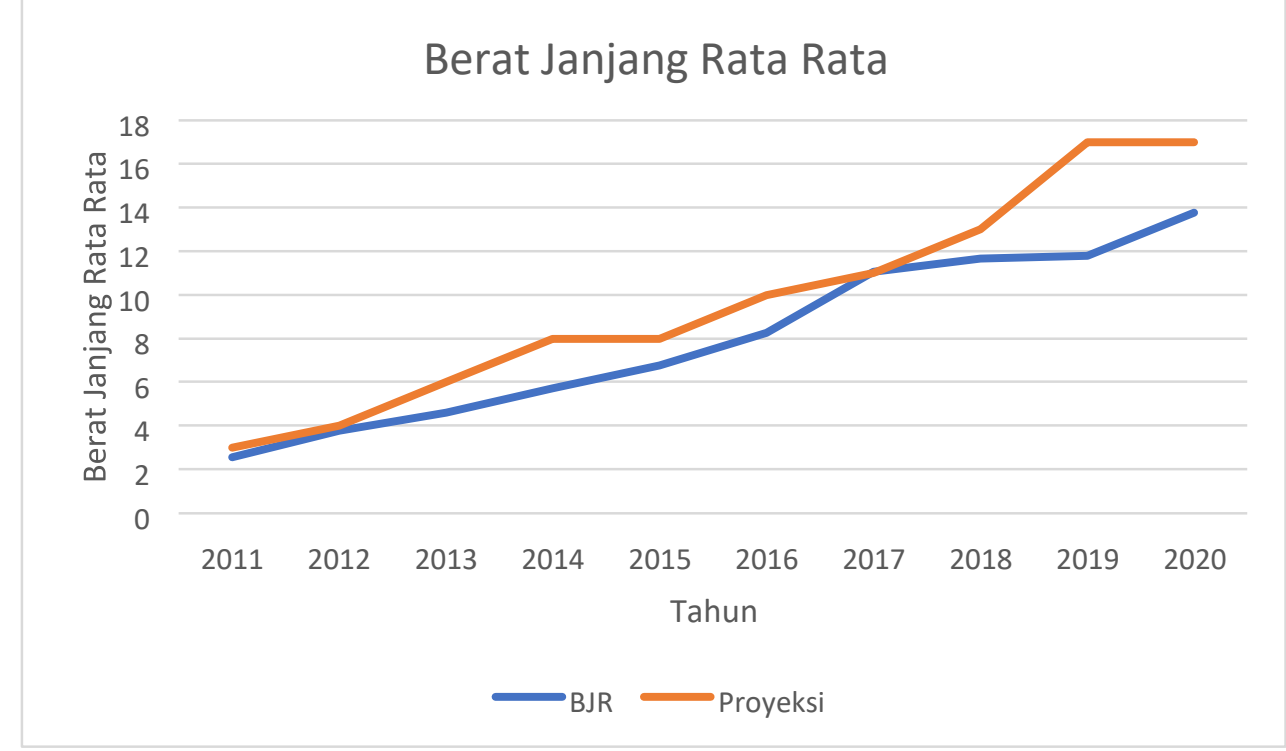

Gambar 10. Grafik Berat Janjang Rata Rata tahun 2011-2020

Dari Gambar 10 memunjukkan bahwa kenaikan BJR terjadi pada tahun 20112017 dan kenaikan BJR relative stabil pada tahun 2017-2019, hal ini terjadi diduga karena 
curah hujan yang tinggi sehingga berpengaruh terhadap penurunan berat janjang rata rata pada blok tersebut.

Dari gambar 10 menunjukkan bahwa berat janjang rata rata dari tahun 2011-2020 mengalami kenaikan tetapi sulit mencapai standar, hanya pada tahun 2017 berat janjang rata rata dapat mencapai standar, hal ini disebabkan tingginya curah hujan yang menyebabkan penurunan berat janjang karena pekerja tidak dapat maksimal dalam menyelesaikan pekerjaan sesuai yang telah ditargetkan dan terjadi losses produksi seperti tidak terkutipnya brondolan, kondisi pasar pikul yang basah akan menyulitkan pekerja dalam mengangkut buah ke tempat pengumpulan hasil menyulitkan perkerja dalam mengangkut buah ke tempat pengumpulan hasil sehingga pekerja kurang efisien waktu dalam pekerjaannya yang berakibat kurang tercapainya target.

Pembuatan infrastruktur pendukung menjadi salah satu hal yang diperlukan dilahan gambut seperti alat pemantau tinggi muka air, saluran air, dan pintu air (stop log), alat pemantau tinggi muka air digunakan sebagai alat ukur ketinggian muka air guna mengetahui apakah lahan gambut kelebihan atau kekurangan air, saluran air baik dari primer, sekunder maupun kuarter perlu dibuat pada lahan gambut sebagai drainase dan irigasi, drainase untuk membuang kelebihan air pada lahan gambut agar air tidak menggenang serta mencipakan keadaan tidak jenuh air untuk pernafasan akar tanaman dapat berjalan dengan baik. Irigasi digunakan untuk menyimpan air apabila pada saat musim kemarau lahan gambut tidak kekurangan air, seperti diketahui apabila lahan gambut sampai kering maka akan mengakibatkan sifat kering tak balik yang berbahaya bagi lingkungan dan tanaman kelapa sawit maka dari itu pengelolaan lahan gambut yang baik apabila dapat mempertahankan ketersediaan air didalam tanah tidak melebihi ambang batas yang telah ditentukan.

\section{KESIMPULAN}

1. Tidak ada korelasi antara curah hujan dengan tinggi muka air tanah (Water Table) dengan persamaan Regresi yang dipilih adalah Regresi linier sederhana yaitu $Y=48,629$ - 0,0612 $X$, dengan koefisien korelasi $(R \wedge 2)=0,331$

2. Untuk hubungan antara curah hujan dengan produksi diperoleh hubungan yang tidak erat dengan nilai koefisien korelasi $(R \wedge 2)=0,4017$ dan dengan persamaan Regresi Linier sederhana yaitu $Y=17,319+0,0465 X$,

3. Hubungan antara tinggi muka air tanah(Water Table) dengan produksi Kelapa sawit diperoleh persamaan regresi Linier sederhana dengan persamaan $Y=48,678-0,601 X$ dan nilai koefisien korelasi nya $(R \wedge 2)=0,759$. 
4. Pengelolaan air di areal gambut pada PT UNI PRIMACOM, Desa Barunang Miri, Kecamatan Parenggean, Kabupaten Kotawaringin Timur, Kalimantan Tengah sudah bagus, yang ditunjukkan oleh tidak adanya hubungan yang erat antara curah hujan dengan tinggi muka air, dan curah hujan dengan produksi, tetapi produksi kelapa sawit justru dipengaruhi oleh tinggi muka air tanah (Water Table) yang ada campur tangan management.

\section{DAFTAR PUSTAKA}

Las, I..K., Nugroho \& Hidayat, A. 2009. Strategi Pemanfaatan Lahan Gambut Untuk Pengembangan Pertanian Berkelanjutan. Balai Besar Penelitian dan Pengembangan Sumberdaya Lahan Pertanian. Bogor. J Pengembangan Inovasi Pertanian 2(4): 295298.

Melling, L., Hatano, R. 2010. Sustainable utilization of tropical peatland for oil palm plantation. Proceeding of Palangkaraya International Symposium \& Workshop On Tropical Peatland. Department of Soil Science and Land Resources Building Bogor Agricultural University.

Putra, D. P., Bimantio, M. P., Sahfitra, A. A., Suparyanto, T., \& Pardamean, B. (2020, August). Simulation of Availability and Loss of Nutrient Elements in Land with Android-Based Fertilizing Applications. In 2020 International Conference on Information Management and Technology (ICIMTech) (pp. 312-317). IEEE.

Saragih, J. M. (2016). Pengelolaan Lahan Gambut di Perkebunan Kelapa Sawit di Riau. Buletin Agrohorti, 4(3), 312-320.

Saragih, D. P. P., Ma'as, A., \& Notohadisuwarno, S. (2019). Various Soil Types, Organic Fertilizers and Doses with Growth and Yields of Stevia rebaudiana Bertoni M. IImu Pertan.(Agricultural Sci, 3(1), 57. 